\title{
Particle partitioning potential of organic compounds is highest in the Eastern US and driven by anthropogenic water
}

\author{
A. G. Carlton and B. J. Turpin \\ Dept. of Environmental Sciences, Rutgers University, New Brunswick, NJ 08901, USA
}

Correspondence to: A. G. Carlton (carlton@envsci.rutgers.edu)

Received: 19 April 2013 - Published in Atmos. Chem. Phys. Discuss.: 14 May 2013

Revised: 31 August 2013 - Accepted: 11 September 2013 - Published: 17 October 2013

\begin{abstract}
Gas-phase water-soluble organic matter $\left(\mathrm{WSOM}_{\mathrm{g}}\right.$ ) is ubiquitous in the troposphere. In the summertime, the potential for these gases to partition to particle-phase liquid water $\left(\mathrm{H}_{2} \mathrm{O}_{\text {ptcl }}\right)$ where they can form secondary organic aerosol $\left(\mathrm{SOA}_{\mathrm{AQ}}\right)$ is high in the Eastern US and low elsewhere, with the exception of an area near Los Angeles, CA. This spatial pattern is driven by mass concentrations of $\mathrm{H}_{2} \mathrm{O}_{\text {ptcl }}$, not WSOMg. $\mathrm{H}_{2} \mathrm{O}_{\text {ptcl }}$ mass concentrations are predicted to be high in the Eastern US, largely due to sulfate. The ability of sulfate to increase $\mathrm{H}_{2} \mathrm{O}_{\text {ptcl }}$ is well established and routinely included in atmospheric models; however $\mathrm{WSOM}_{\mathrm{g}}$ partitioning to this water and subsequent SOA formation is not. The high mass concentrations of $\mathrm{H}_{2} \mathrm{O}_{\text {ptcl }}$ in the southeast (SE) US but not the Amazon may help explain why biogenic SOA mass concentrations are high in the SE US but low in the Amazon. Furthermore, during the summertime in the Eastern US, the potential for organic gases to partition into liquid water is greater than their potential to partition into organic matter $(\mathrm{OM})$ because concentrations of $\mathrm{WSOM}_{\mathrm{g}}$ and $\mathrm{H}_{2} \mathrm{O}_{\text {ptcl }}$ are higher than semi-volatile gases and OM. Thus, unless condensed phase yields are substantially different $(>\sim$ order of magnitude), we expect that SOA formed through aqueous-phase pathways $\left(\mathrm{SOA}_{\mathrm{AQ}}\right)$ will dominate in the Eastern US. These findings also suggest that $\mathrm{H}_{2} \mathrm{O}_{\text {ptcl }}$ is largely anthropogenic and provide a previously unrecognized mechanism by which anthropogenic pollutants impact the amount of SOA mass formed from biogenic organic emissions. The previously reported estimate of the controllable fraction of biogenic SOA in the Eastern US $(50 \%)$ is likely too low.
\end{abstract}

\section{Introduction}

Liquid water is predicted to be the most abundant particlephase species in the atmosphere, 2-3 times total aerosol dry mass globally (Liao and Seinfeld, 2005). However, chemical mechanisms employed in photochemical transport models largely underrepresent the impact of partitioning and oxidation reactions in aqueous media, in particular for organic species. This hinders development of effective strategies for air quality management and climate mitigation because important processes, feedbacks and anthropogenic influences are missing from model predictions.

Formation of secondary organic aerosol (SOA) through partitioning of semi-volatile products of gas-phase photochemical reactions into preexisting particulate organic matter $(\mathrm{OM})\left(\mathrm{SOA}_{\text {gas }}\right)$ is well established. For more than 20 years, empirical relationships developed from relatively dry SOA smog chamber studies conducted with little particlephase liquid water (e.g., relative humidity $(\mathrm{RH})<20 \%$, Griffin et al., 1999; $\mathrm{Ng}$ et al., 2007) have provided critical data for atmospheric modeling of organic aerosol (Pankow, 1994; Odum et al., 1996; Seinfeld and Pankow, 2003). Despite studies of the effects of liquid water on the gasparticle partitioning of these semi-volatile products (Pun et al., 2002; Zuend and Seinfeld, 2012), atmospheric application of chamber-derived relationships describing $\mathrm{SOA}_{\text {gas }}$ remains problematic (Chang et al., 2010). This could be, at least in part, because derived empirical formulations do not include the potential for polar organic gases to partition to polar solvents such as water, and react in that medium to form low-volatility products. Parikh et al. $(2011,2012)$ find that when an Odum 2-product or volatility basis set (VBS) SOA model is applied to independent smog chamber studies 
where relative humidity $(\mathrm{RH})$ and particle-phase liquid water concentrations $\left(\mathrm{H}_{2} \mathrm{O}_{\text {ptcl }}\right)$ are more typical of general atmospheric conditions, SOA parameterizations cannot reproduce observed amounts or trends in SOA mass (Parikh et al., 2011, 2012). In a series of experiments conducted in an outdoor chamber, accounting for gas-phase formation of watersoluble gases followed by partitioning into aerosol water was necessary to describe observed SOA mass accurately (Parikh et al., 2011, 2012). It is important to note available $\mathrm{H}_{2} \mathrm{O}_{\text {ptcl }}$ is a function not only of RH but also of particle concentration and hygroscopicity (Zhou et al., 2011). Measurement of RH alone is not sufficient to determine $\mathrm{H}_{2} \mathrm{O}_{\text {ptcl }}$.

Gas-phase photochemistry oxidizes and fragments biogenic and anthropogenic volatile organic compounds (VOCs) resulting in the ubiquitous and abundant presence of small, water-soluble organic compounds (e.g., formic and acetic acids, glyoxal, methylglyoxal, acetone) (Spaulding et al., 2003). These compounds are too small to form SOA through traditional semi-volatile partitioning theory in atmospheric models (e.g., SOA $\mathrm{Sas}_{\text {) }}$ ). However, it is now accepted that water-soluble compounds react in atmospheric waters (clouds, fogs and wet aerosols) to form SOA (Blando and Turpin, 2000; Ervens et al., 2011; Liu et al., 2012a). Evidence for SOA formation from gas followed by aqueous chemistry $\left(\mathrm{SOA}_{\mathrm{AQ}}\right)$ is provided by laboratory experiments conducted at concentrations typical of atmospheric waters (e.g., with $\mathrm{OH}$ radicals and other reactants) that demonstrate formation of compounds found predominantly in the particle phase in the atmosphere: organic acids/salts (e.g., oxalate), high molecular weight compounds (HMWC) including oligomers, and sulfur- and nitrogen-containing organics (Carlton et al., 2006; Altieri et al., 2006, 2008; Guzman et al., 2006; Carlton et al., 2007; Noziere and Cordova, 2008; Volkamer et al., 2009; Galloway et al., 2009; Shapiro et al., 2009; De Haan et al., 2009a, b; El Haddad et al., 2009; Perri et al., 2009, 2010; Yao Liu et al., 2009, Liu et al., 2012b, c; Noziere et al., 2009, 2010; Yasmeen et al., 2010; Tan et al., 2010; Sun et al., 2010; Sareen et al., 2010; Grgic et al., 2010; Poulain et al., 2010; Zhang et al., 2010; Huang et al., 2011; Lee et al., 2011; Tan et al., 2012; Ortiz-Montalvo et al., 2012; Zarzana et al., 2012; Nguyen et al., 2012).

The analysis herein suggests that, as is the case for $\mathrm{SOA}_{\text {gas }}$ (Lane et al., 2008; Carlton et al., 2010b), anthropogenic pollution enhances the formation of biogenic $\mathrm{SOA}_{\mathrm{AQ}}$. We propose that this anthropogenic enhancement of biogenic $\mathrm{SOA}_{\mathrm{AQ}}$ occurs because sulfur pollution increases the amount of $\mathrm{H}_{2} \mathrm{O}_{\text {ptcl }}$ at a given relative humidity (RH) (Malm et al., 1994). In many locations including the Eastern US, SOA is predominantly formed from biogenic hydrocarbons (Lewis et al., 2004; Kleindienst et al., 2007; Ding et al., 2008). However, correlations between biogenic SOA mass and tracers of anthropogenic pollution are strong suggesting that anthropogenic pollution plays an important role in biogenic SOA formation (De Gouw and Jimenez, 2009). In fact anthropogenic aerosol water could potentially drive biogenic SOA formation in high $\mathrm{RH}$ locations by providing the partitioning medium $\left(\mathrm{H}_{2} \mathrm{O}_{\mathrm{ptcl}}\right)$ for $\mathrm{SOA}_{\mathrm{AQ}}$ formation. There is observational evidence suggesting enhancement of biogenic SOA mass derived from isoprene oxidation products when sulfate is present in the Eastern US (Chan et al., 2010), in particular when RH is high (Hatch et al., 2011). Anthropogenic pollution has been estimated to be responsible for roughly half of the biogenic SOA mass in the Eastern US (Carlton et al., 2010b). While anthropogenic $\mathrm{H}_{2} \mathrm{O}_{\text {ptcl }}$ was estimated in those simulations, Gas-phase water-soluble organic matter $\left(\mathrm{WSOM}_{\mathrm{g}}\right)$ partitioning and subsequent $\mathrm{SOA}_{\mathrm{AQ}}$ formation in wet aerosol was not included. Thus the $50 \%$ estimate is likely too low. Further, anthropogenic influences on $\mathrm{H}_{2} \mathrm{O}_{\text {ptcl }}$ would also increase SOA derived from anthropogenic VOCs, which also oxidize to form gas-phase $\mathrm{WSOM}_{\mathrm{g}}$.

To explore potential drivers of spatial differences in observed SOA mass, we use a 3-dimensional photochemical transport model to predict mixing ratios of gas-phase organic compounds and mass concentrations of particulate species. We use these predictions to evaluate spatial trends in the overall solubility of organic gas-phase inventories, particlephase concentrations of liquid water $\left(\mathrm{H}_{2} \mathrm{O}_{\mathrm{ptcl}}\right)$, and particulate OM. We use these predictions to estimate the chemical potential of organic gases to partition into liquid water. We also compare this potential (qualitatively) to the partitioning of semi-volatile organic gases into OM.

\section{Methods}

Version 4.7 of the Community Multiscale Air Quality (CMAQ) (www.cmascenter.org) model is applied to predict the photochemistry and transport of atmospheric trace species over the continental US for July 2003. Observational estimates during this time period indicate that secondary organic carbon is a substantial fraction of total particle carbon mass (Kleindienst et al., 2007).

\subsection{CMAQ model simulations}

CMAQ simulation details and inputs are described in detail elsewhere (Carlton et al., 2010b). Briefly, CMAQv4.7, with SOA formation (Carlton et al., 2010a) and aqueous-phase chemistry of sulfur, glyoxal and methylglyoxal in clouds (Carlton et al., 2008), is applied. The MM5 meteorology model, EPA's 2002 National Emissions Inventory (NEIv2) and the Biogenic Emission Inventory System (BEIS) (Pierce et al., 1998) are used to drive transport and develop anthropogenic and biogenic emissions, projected hourly for input to CMAQ with SMOKE (Houyoux et al., 2000). The SAPRC99 gas-phase chemical mechanism was used to simulate gasphase photochemistry. The model domain is resolved horizontally with $36 \mathrm{~km} \times 36 \mathrm{~km}$ grid cells and vertically up to $100 \mathrm{mb}$ with 14 vertical layers, with most resolution near the surface. Presented results are averages for July 2003. 
Aerosol-free acidity is calculated in $\mathrm{nmol} \mathrm{m}^{-3}$ from CMAQ predictions of Aitken and accumulation mode aerosol as

$\mathrm{H}^{+}=1000\left[2 \frac{\mathrm{SO}_{4}^{2-}}{96}+\frac{\mathrm{NO}_{3}^{-}}{62}+\frac{\mathrm{Cl}^{-}}{35}-\frac{\mathrm{Na}^{+}}{23}-\frac{\mathrm{NH}_{4}^{+}}{18}\right]$.

The ion mass concentrations are calculated from the following CMAQ output species: $\mathrm{SO}_{4}=\mathrm{ASO} 4 \mathrm{I}+\mathrm{ASO} 4 \mathrm{~J} ; \mathrm{NO}_{3}$ $=\mathrm{ANO} 3 \mathrm{I}+\mathrm{ANO} 3 \mathrm{~J} ; \mathrm{Cl}=\mathrm{ACLJ} ; \mathrm{Na}=\mathrm{ANAJ} ;$ and $\mathrm{NH}_{4}=$ ANH4I + ANH4J. A in the species name denotes aerosol, I the Aitken mode, and $\mathrm{J}$ the accumulation mode.

\subsection{Water-soluble and semi-volatile gases}

Organic gases listed in Table 1 are simulated in the CMAQ model when SAPRC is employed. Mixing ratios of each species are converted from $\mathrm{ppb}_{\mathrm{V}}$ to $\mathrm{ppb}_{\mathrm{v}} \mathrm{C}$, and mass concentrations are calculated in $\mu \mathrm{g} \mathrm{m}^{-3}$ using the ideal gas law and MM5-predicted air density. The sum of water-soluble gases simulated by CMAQ and shown in laboratory experiments to make SOA through aqueous-phase processes at concentrations typical of wet aerosol - glyoxal (Carlton et al., 2007), methylglyoxal (Tan et al., 2010), acetaldehyde (Li et al., 2011), methacrolein (El Haddad et al., 2009), phenols (Sun et al., 2010), acetone (Poulain et al., 2010), acetic acid (Tan et al., 2012) and glycolaldehyde (Perri et al., 2010) - is calculated as $\mathrm{WSOM}_{\mathrm{g}}$. Glycolaldehyde is not an explicit species in SAPRC99 and is counted as half of model species "RCHO". It should be recognized that this summation is a lower bound estimate of $\mathrm{WSOM}_{\mathrm{g}}$ with the potential to form $\mathrm{SOA}_{\mathrm{AQ}}$. Other water-soluble gases undoubtedly also form $\mathrm{SOA}_{\mathrm{AQ}}$. Formaldehyde, an abundant watersoluble gas, forms particle-phase hydroxymethanesulfonate in the presence of sulfur through aqueous-phase processes (Munger et al., 1984), but is not counted here. Only half of model species "RCHO" (C3 aldehydes and higher) was counted in the sum, but the uncounted RCHO mass will also likely form $\mathrm{SOA}_{\mathrm{AQ}}$ to some degree similar to aldehydes that are considered (glyoxal, methylglyoxal, glycolaldehyde). Further, gas-phase isoprene photooxidation produces water-soluble epoxides (Paulot et al., 2009) recently detected in ambient particulate samples in the Southeast US (Budisulistiorini et al., 2013) but not included in this model simulation. The semi-volatile gas-phase species are the first and second products from isoprene, monoterpenes, sesquiterpenes, benzene, long-chain alkanes, toluenes and xylenes that form SOA in CMAQ (Carlton et al., 2010a) through semi-volatile partitioning (Odum et al., 1996) ( $\mathrm{SOA}_{\text {gas }}$ ). It should be noted that in reality some fraction of species included in the semi-volatile class would likely also partition to liquid water (Chang et al., 2010).

\subsection{Methylglyoxal-equivalent solubility}

In order to account for the combined effects of compoundspecific water solubility and concentration, a solubility in- dex for describing concentrations of all organic gases was adopted (e.g., not only water-soluble species for which laboratory experiments have been conducted, but all CMAQmodeled species). Methylglyoxal is used as a reference compound because, as an oxidation product of both biogenic and anthropogenic hydrocarbons (Paulson and Seinfeld, 1992; Smith et al., 1999; Atkinson and Arey, 2003; Ham et al., 2006), it is found widely in urban and rural environments (Spaulding et al., 1999, 2003; Moortgat et al., 2002; Wang et al., 2002; $\mathrm{Li}$ and $\mathrm{Yu}, 2005$; Ho et al., 2006). In this method, analogous to the propylene-equivalent concentration used in reactivity calculations (Chameides et al., 1992), a methylglyoxal-equivalent concentration is calculated for each organic species $\mathbf{J}$ in the SAPRC99 mechanism using values in Table 1.

$\operatorname{MGLY}_{\text {equiv }}(\mathrm{J})=\left[C_{\mathrm{J}}\right] \frac{H_{\mathrm{L}, \mathrm{J}}}{H_{\mathrm{L}, \mathrm{MGLY}}}$,

where $C_{\mathrm{J}}$ is the concentration of organic species $\mathrm{J}, H_{\mathrm{L}, \mathrm{J}}$ the Henry's law constant for species $\mathrm{J}$, and $H_{\mathrm{L}, \mathrm{MGLY}}$ the Henry's law constant for methylglyoxal. Henry's law constants are adjusted to hour-specific model-predicted temperature when appropriate (Table 1). MGLY equiv is the concentration of species $\mathbf{J}$ on a scale normalized to the solubility of methylglyoxal. MGLY equiv is the gas-phase mass concentration of methylglyoxal needed to generate an equal amount of partitionable (gas-to-aqueous) organic mass of species $\mathrm{J}$. The concentration is calculated in $\mu \mathrm{g} \mathrm{m}^{-3}$ to investigate trends and patterns in gas-phase water-soluble organic matter $\left(\mathrm{WSOM}_{\mathrm{g}}\right)$. In this context, if gas-phase organic species $\mathbf{J}$ had an atmospheric abundance of $10 \mu \mathrm{g} \mathrm{m}^{-3}$ and were twice as soluble as methylglyoxal, it would have a MGLY equiv concentration of $20 \mu \mathrm{g} \mathrm{m}^{-3}$; if the species were half as soluble as methylglyoxal, it would have a MGLY equiv concentration of $5 \mu \mathrm{g} \mathrm{m}^{-3}$. Because this solubility-based method accounts for a species' solubility as well as its atmospheric concentration, it provides an estimate of the relative contribution each organic species can make to the flux of gas-phase organic matter to aerosol water. It also provides a framework to compare spatial differences in the overall gas-phase organic solubility for a particular inventory.

\subsection{Instantaneous aqueous partitioning potential}

The overall potential for organic gas-to-liquid water partitioning is dependent not only on the concentration and water solubility of organic gases but also on the spatial and temporal co-location (or not) of liquid water. In this work we consider only particle-phase liquid water $\left(\mathrm{H}_{2} \mathrm{O}_{\text {ptcl }}\right)$. The mass concentration of $\mathrm{H}_{2} \mathrm{O}_{\text {ptcl }}$ is predicted in CMAQ with ISORROPIA from water vapor mixing ratios and concentrations of inorganic species. In ISORROPIA, partitioning of inorganic species and atmospheric water between the gas phase and aerosol phase is calculated using relative humidity and molality of an aqueous binary solution of species containing 


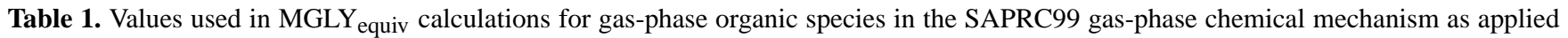
in CMAQv4.7.

\begin{tabular}{|c|c|c|c|c|}
\hline $\begin{array}{l}\text { Species mechanism } \\
\text { name }\end{array}$ & Species description & $\begin{array}{l}\mathrm{MW} \\
\mathrm{g} \mathrm{mol}^{-1}\end{array}$ & $\begin{array}{l}\text { No. of } \\
\text { C atoms }\end{array}$ & $\mathrm{H}_{1} \mathrm{~mol} \mathrm{~atm}^{-1}$ \\
\hline $\mathrm{HCHO}$ & formaldehyde & 30 & 1 & $3.2 \mathrm{e} 03 \times \exp \left(6.8 \mathrm{e} 03 \times T_{\mathrm{fac}}\right)$ \\
\hline $\mathrm{CCHO}$ & acetaldehyde & 44 & 2 & $1.4 \mathrm{e} 01 \times \exp \left(5.6 \mathrm{e} 03 \times T_{\mathrm{fac}}\right)$ \\
\hline $\mathrm{RCHO}$ & lumped $\mathrm{C} 3+$ aldehydes & 58 & 3 & $4.20 \mathrm{E}+03$ \\
\hline ACET & acetone & 58 & 3 & $3.0 \mathrm{e} 01 \times \exp \left(4.6 \mathrm{e} 03 \times T_{\mathrm{fac}}\right)$ \\
\hline MEK & $\begin{array}{l}\text { ketones (and other non-aldehydes) with } \\
k_{\mathrm{OH}}<5 \times 10^{-12} \mathrm{~cm}^{3} \mathrm{molec}^{-2} \mathrm{~s}^{-1}\end{array}$ & 72 & 3 & $2.0 \mathrm{e} 01 \times \exp \left(5.0 \mathrm{e} 03 \times T_{\mathrm{fac}}\right)$ \\
\hline $\mathrm{MEOH}$ & methanol & 32 & 1 & $2.20 \mathrm{E}+02$ \\
\hline $\mathrm{COOH}$ & methyl hydroperoxide & 48 & 1 & $3.1 \mathrm{e} 02 \times \exp \left(5.2 \mathrm{e} 03 \times T_{\mathrm{fac}}\right)$ \\
\hline $\mathrm{ROOH}$ & lumped higher organic hydroperoxides & 62 & 2 & $3.1 \mathrm{e} 02 \times \exp \left(5.2 \mathrm{e} 03 \times T_{\mathrm{fac}}\right)$ \\
\hline GLY & glyoxal & 58 & 2 & $3.60 \mathrm{E}+05$ \\
\hline MGLY & methylglyoxal & 72 & 3 & $3.20 \mathrm{E}+04$ \\
\hline BACL & biacetyl & 86 & 4 & $7.4 \mathrm{e} 01 \times \exp \left(5.7 \mathrm{e} 03 \times T_{\mathrm{fac}}\right)$ \\
\hline PHEN & phenol & 94 & 6 & $1.9 \mathrm{e} 03 \times \exp \left(7.3 \mathrm{e} 03 \times T_{\mathrm{fac}}\right)$ \\
\hline CRES & cresols & 108 & 7 & $8.20 \mathrm{E}+02$ \\
\hline BALD & aromatic aldehydes (e.g., benzaldehyde) & 106 & 7 & $3.9 \mathrm{e} 01 \times \exp \left(4.8 \mathrm{e} 03 \times T_{\mathrm{fac}}\right)$ \\
\hline METHACRO & methacrolein & 70 & 4 & $6.50 \mathrm{E}+00$ \\
\hline MVK & methyl vinyl ketone & 70 & 4 & $4.10 \mathrm{E}+01$ \\
\hline ISOPROD & lumped isoprene products & 70 & 4 & $4.10 \mathrm{E}+01$ \\
\hline PROD2 & $\begin{array}{l}\text { ketones (and other non-aldehydes) with } \\
k_{\mathrm{OH}}>5 \times 10^{-12} \mathrm{~cm}^{3} \mathrm{molec}^{-2} \mathrm{~s}^{-1}\end{array}$ & 100 & 4 & $4.10 \mathrm{E}+01$ \\
\hline DCB 1 & $\begin{array}{l}\text { reactive aromatic fragmentation products that do } \\
\text { not undergo significant photodecomposition }\end{array}$ & 58 & 3 & $8.20 \mathrm{E}+00$ \\
\hline DCB2 & $\begin{array}{l}\text { reactive aromatic fragmentation products that pho- } \\
\text { tolyze with } \alpha \text {-dicarbonyl-like action spectrum }\end{array}$ & 72 & 4 & $8.20 \mathrm{E}+00$ \\
\hline DCB3 & $\begin{array}{l}\text { reactive aromatic fragmentation products that pho- } \\
\text { tolyze with acrolein action spectrum }\end{array}$ & 72 & 4 & $8.20 \mathrm{E}+00$ \\
\hline $\mathrm{HCOOH}$ & formic acid & 46 & 1 & $8.9 \mathrm{e} 03 \times \exp \left(6.1 \mathrm{e} 03 \times T_{\mathrm{fac}}\right)$ \\
\hline CCO_OOH & peroxy acetic acid & 76 & 2 & $4.1 \mathrm{e} 03 \times \exp \left(6.3 \mathrm{e} 03 \times T_{\mathrm{fac}}\right)$ \\
\hline RCO_OH & higher organic acids & 74 & 3 & $5.70 \mathrm{E}+03$ \\
\hline CCO_OH & acetic acid & 60 & 2 & $8.4 \mathrm{e} 02 \times \exp \left(5.3 \mathrm{e} 03 \times T_{\mathrm{fac}}\right)$ \\
\hline RCO_OOH & higher organic peroxy acids & 90 & 3 & $5.70 \mathrm{E}+03$ \\
\hline ETHENE & ethene & 28 & 2 & 4.70E-03 \\
\hline ISOPRENE & isoprene & 68 & 5 & $2.80 \mathrm{E}-02$ \\
\hline ALK1 & $\begin{array}{l}\text { alkanes (and other non-aromatics) that react only } \\
\text { with } \mathrm{OH}, k_{\mathrm{OH}}<5 \times 10^{2} \mathrm{ppm}^{-1} \mathrm{~min}^{-1} \\
\text { (primarily ethane) }\end{array}$ & 30.1 & 2 & $1.9 \mathrm{E}-03 \times \exp \left(2.3 \mathrm{e} 03 \times T_{\mathrm{fac}}\right)$ \\
\hline ALK2 & $\begin{array}{l}\text { alkanes (and other non-aromatics) that react only } \\
\text { with } \mathrm{OH}, 5 \times 10^{2}<k_{\mathrm{OH}}<2.5 \times 10^{3} \mathrm{ppm}^{-1} \mathrm{~min}^{-1} \\
\text { (primarily propane and acetylene) }\end{array}$ & 36.7 & 3 & $0.0015 \times \exp \left(2.7 \mathrm{e} 03 \times T_{\mathrm{fac}}\right)$ \\
\hline ALK3 & $\begin{array}{l}\text { alkanes (and other non-aromatics) that react only } \\
\text { with } \mathrm{OH}, 2.5 \times 10^{3}<k_{\mathrm{OH}}<5 \times 10^{3} \mathrm{ppm}^{-1} \mathrm{~min}^{-1}\end{array}$ & 58.6 & 4 & $1.10 \mathrm{E}-03$ \\
\hline ALK4 & $\begin{array}{l}\text { alkanes (and other non-aromatics) that react only } \\
\text { with } \mathrm{OH}, 5 \times 10^{3}<k_{\mathrm{OH}}<1 \times 10^{4} \mathrm{ppm}^{-1} \mathrm{~min}^{-1}\end{array}$ & 77.6 & 5 & $1.10 \mathrm{E}-03$ \\
\hline ALK5 & $\begin{array}{l}\text { alkanes (and other non-aromatics) that react only } \\
\text { with } \mathrm{OH}, k_{\mathrm{OH}}>1 \times 10^{4} \mathrm{ppm}^{-1} \mathrm{~min}^{-1}\end{array}$ & 118.9 & 8 & $1.40 \mathrm{E}-04$ \\
\hline ARO1 & aromatics with $k_{\mathrm{OH}}<2 \times 10^{4} \mathrm{ppm}^{-1} \min ^{-1}$ & 98.6 & 7 & $1.5 \mathrm{e}-01 \times \exp \left(4.0 \mathrm{e} 03 \times T_{\text {fac }}\right)$ \\
\hline $\mathrm{ARO} 2$ & aromatics with $k_{\mathrm{OH}}>2 \times 10^{4} \mathrm{ppm}^{-1} \mathrm{~min}^{-1}$ & 118.7 & 8 & $1.9 \mathrm{e}-01 \times \exp \left(4.0 \mathrm{e} 03 \times T_{\text {fac }}\right)$ \\
\hline OLE1 & $\begin{array}{l}\text { alkenes (other than ethene) with } \\
k_{\mathrm{OH}}<7 \times 10^{4} \mathrm{ppm}^{-1} \mathrm{~min}^{-1}\end{array}$ & 72.3 & 6 & $4.70 \mathrm{E}-03$ \\
\hline OLE2 & alkenes with $k_{\mathrm{OH}}>7 \times 10^{4} \mathrm{ppm}^{-1} \mathrm{~min}^{-1}$ & 75.8 & 6 & 4.70E-03 \\
\hline TRP1 & terpenes & 136 & 10 & 4.90E-02 \\
\hline SESQ & sesquiterpenes & 204 & 15 & 4.90E-02 \\
\hline BENZENE & benzene & 78 & 6 & $1.6 \mathrm{e}-01 \times \exp \left(4.1 \mathrm{e} 03 \times T_{\text {fac }}\right)$ \\
\hline
\end{tabular}

$T_{\text {fac }}=(298-\mathrm{Temp}) /(298 \times \mathrm{Temp})$ 
a) WSOM mixing ratio at surface

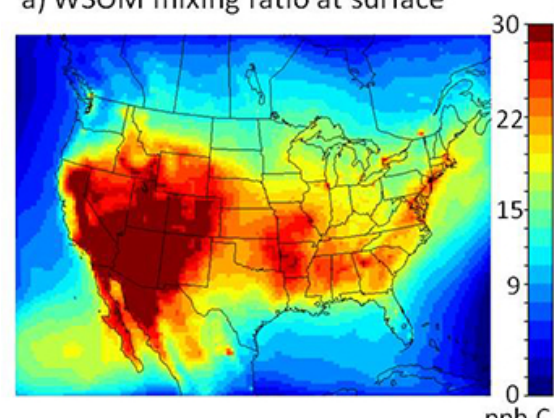

b) Surface WSOM mass concentration

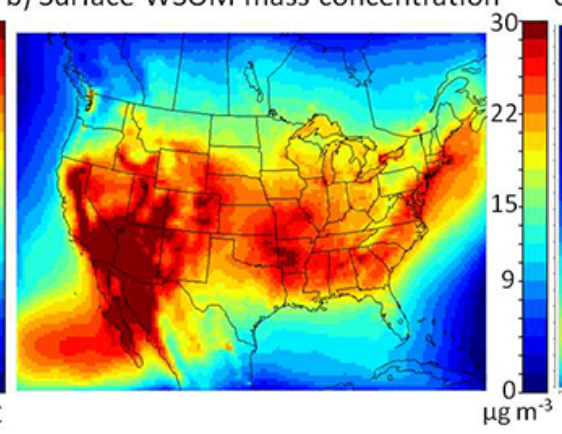

c) WSOM column mass concentration

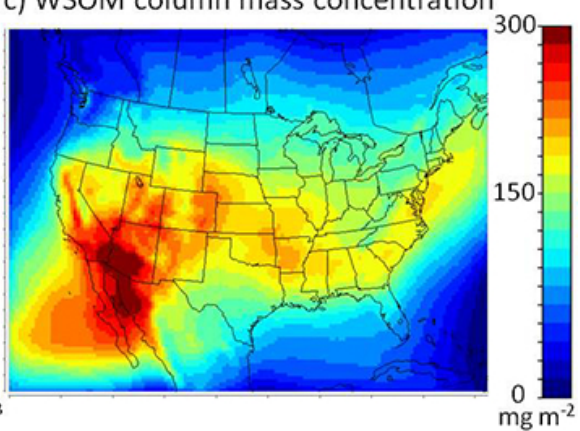

Fig. 1. (a) Sum of gas-phase CMAQ water-soluble organic gases shown in lab experiments to make SOA $\mathrm{AQ}$ : glyoxal (Carlton et al., 2007), methylglyoxal (Tan et al., 2010), acetaldehyde (Li et al., 2011), phenols (Sun et al., 2010), acetone (Poulain et al., 2010), acetic acid (Tan et al., 2012), methacrolein (El Haddad et al., 2009) and glycolaldehyde (Perri et al., 2010). Note that glycolaldehyde is not an explicit species in SAPRC99 (used in this simulation) and is counted as half of model species "RCHO". For the mixing ratio (a), all gases are presented in $\mathrm{ppb}_{\mathrm{V}}$-carbon. The mass concentrations in (b) and (c) are converted from the molar ratios using the ideal gas law. Values are July 2003 averages.

sulfate, nitrate, chlorine, sodium and ammonium (Nenes et al., 1999). The partitioning potential of $\mathrm{WSOM}_{\mathrm{g}}$ to liquid water is calculated with a thermodynamic equilibrium assumption as is done for gas-phase organic species that partition to OM (Pankow, 1994). The potential is calculated here:

$$
\begin{aligned}
P_{\text {WSOM P }}(\mathrm{J}) & =\left[C_{\mathrm{J}}\right]\left[C_{\mathrm{H}_{2} \mathrm{O}}\right] \frac{H_{\mathrm{J}}}{H_{\mathrm{MGLY}}} \phi_{\mathrm{J}} \\
& =\mathrm{MGLY}_{\text {equiv }}\left[C_{\mathrm{H}_{2} \mathrm{O}}\right] \phi_{\mathrm{J}},
\end{aligned}
$$

where $C_{\mathrm{J}}$ is the concentration of organic species $\mathrm{J}\left(\mu \mathrm{g} \mathrm{m}^{-3}\right)$ and $C_{\mathrm{H}_{2} \mathrm{O}}$ is the liquid water concentration $\left(\mathrm{H}_{2} \mathrm{O}_{\mathrm{ptcl}}\right)$ $\left(\mu \mathrm{g} \mathrm{m}^{-3}\right) . \phi_{\mathrm{J}}$ is referred to as the $\mathrm{SOA}_{\mathrm{AQ}}$-forming potential, analogous to incremental reactivity in ozone studies (Chameides et al., 1992). $\phi_{\mathrm{J}}$ represents the likelihood organic mass will remain in the condensed phase after partitioning, for example by being transformed into low-volatility products through radical and non-radical reactions (Ervens et al., 2011). $\phi_{\mathrm{J}}$ depends on a variety of factors including the presence of other aqueous species/reactants (e.g., $\mathrm{OH}$ radicals, $\mathrm{NH}_{3}$ ), yields of low-volatility products from such aqueous reactions and local meteorology (e.g., temperature and $\mathrm{RH})$. Values of $\phi_{\mathrm{J}}$ are not currently known and are likely not constant. To explore sensitivity of the partitioning potential to $\phi$, we perform two calculations with constant $\phi$ values: the first with $\phi$ set to 1 and another with $\phi$ set to 0.1 for all species. These assumptions are not correct and represent non-trivial limitations of the framework, but regardless the partitioning potential is useful as an index that identifies areas where $\mathrm{SOA}_{\mathrm{AQ}}$ is likely to be important. In assessing this partitioning potential, the relative importance of one organic species to another will depend not only upon the relative concentrations of the compound in the MGLY equiv index but also upon the liquid water content of the air mass. For this reason, a highly soluble species with a large concentration will not necessarily be an important precursor if not co-located with $\mathrm{H}_{2} \mathrm{O}_{\text {ptcl }}$ in space and time.

\subsection{Limitations}

There are uncertainties when calculating partitioning potentials and comparing pathways. First, the degree to which CMAQ accurately represents particle-phase liquid water mass is not well understood. CMAQ might underpredict $\mathrm{H}_{2} \mathrm{O}_{\text {ptcl }}$ because ISORROPIA, the thermodynamic partitioning model implemented in CMAQ and employed to predict particle-phase liquid water, includes only inorganic species. In laboratory studies, organic compounds ubiquitous in the troposphere (e.g., methylglyoxal and acetaldehyde) increase particle hygroscopicity (Sareen et al., 2013), and particlephase organic material is reported to contribute to $\mathrm{H}_{2} \mathrm{O}_{\text {ptcl }}$ in several locations (Dick et al., 2000; Canepari et al., 2013). Second, it is well established that CMAQv4.7 underpredicts secondary organic aerosol mass (Carlton et al., 2010a; Carlton and Baker, 2011). The uncertainties in $\mathrm{H}_{2} \mathrm{O}_{\text {ptcl }}$, OM, $\mathrm{WSOM}_{\mathrm{g}}$ and semi-volatile gas-phase species constitute the major limitations of this assessment.

Organic species are often found in the aerosol aqueous phase at concentrations higher than predicted by Henry's law (e.g., glyoxal; Kroll et al., 2005). Nevertheless, Henry's law constants are predictors of organic gas-to-aqueous partitioning and therefore useful in a "partitioning potential" calculation. The assumption of constant $\phi_{\mathrm{J}}=1$ or 0.1 for all organic species is not correct. Appropriate values for $\phi$ are not well understood. The results herein provide a framework to identify species, locations and times where $\mathrm{SOA}_{\mathrm{AQ}}$ formation is likely to be important, and further investigation is warranted. 

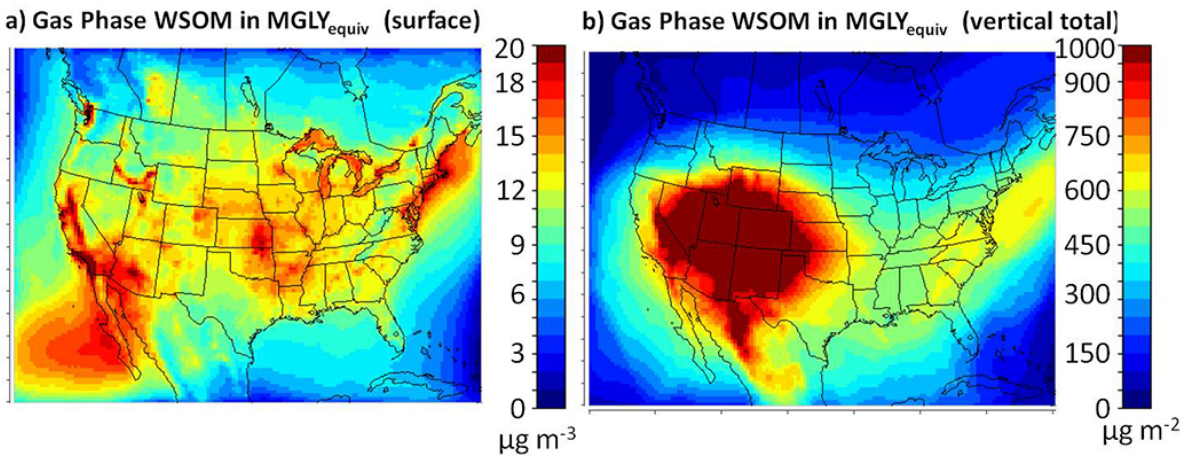

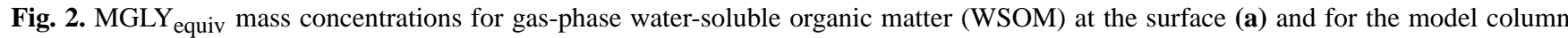
(surface to $100 \mathrm{mb}$ ) (b). Note that all species included in Table 1 are used in the calculation of MGLY equiv. Values are July 2003 averages.
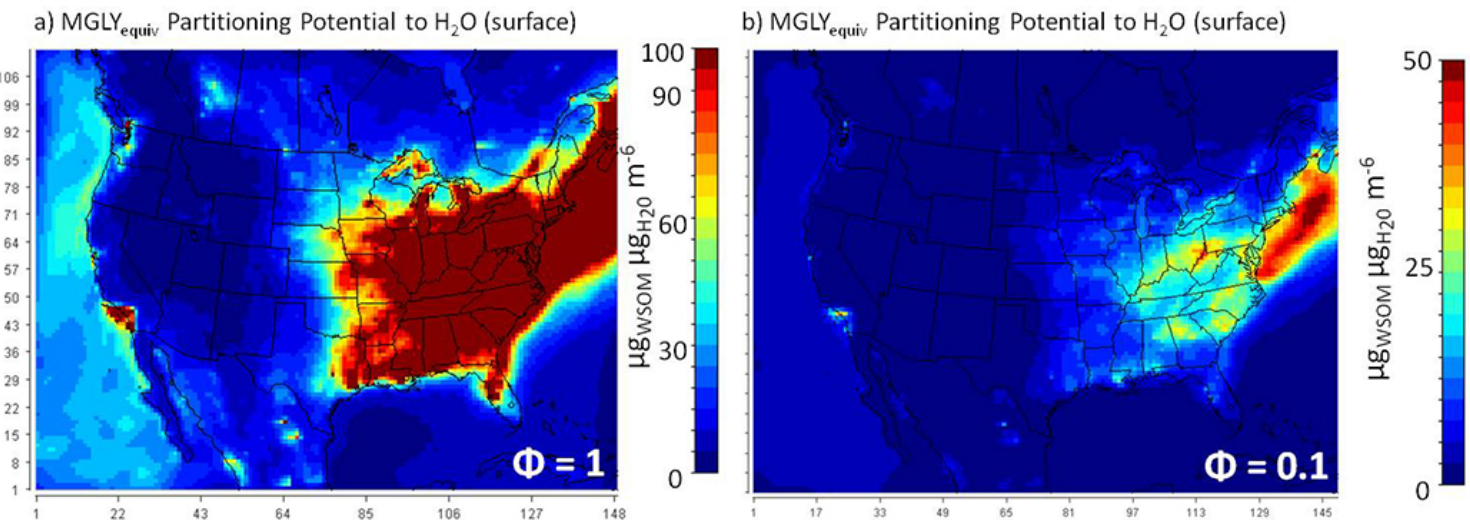

c) MGLY equiv Partitioning Potential to $\mathrm{H}_{2} \mathrm{O}$ (vertical total)
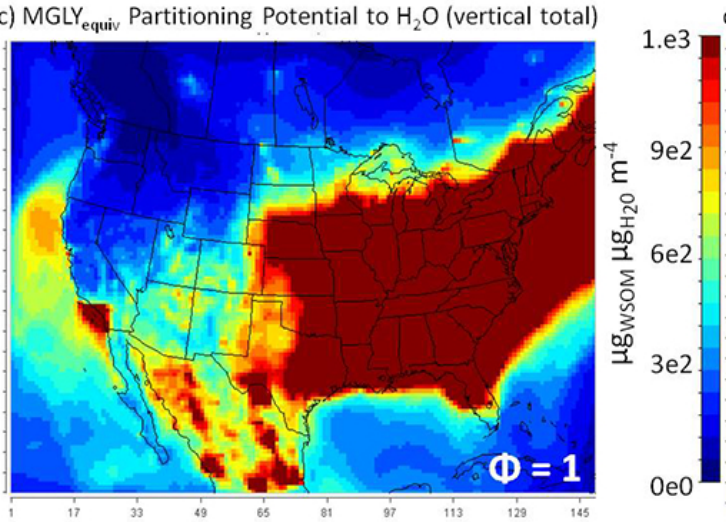

d) $M G L Y_{\text {equiv }}$ Partitioning Potential to $\mathrm{H}_{2} \mathrm{O}$ (vertical total)
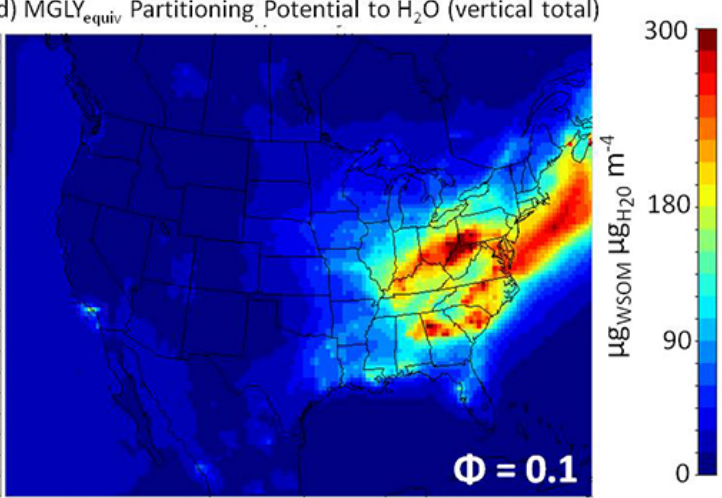

Fig. 3. CInstantaneous partitioning potential for gas-phase water-soluble organic matter (WSOM) as MGLY equiv to partition to particle phase liquid water at the surface for $\phi=1$ (a) and $\phi=0.1$ (b), and for the model column (up to $100 \mathrm{mb}$ ) for $\phi=1$ (c) and $\phi=0.1$ (d). Values are July 2003 averages.

\section{Results}

\subsection{Ubiquity of water-soluble organic gases}

In the summertime, throughout the troposphere over the continental US water-soluble organic gases, demonstrated to form SOA in laboratory experiments through aqueous-phase chemistry, are ubiquitous (Fig. 1). This finding is consis- tent with a variety of ambient measurements that indicate WSOM $_{\mathrm{g}}$ is abundant (Chebbi and Carlier, 1996; Nolte et al., 1999; Hennigan et al., 2009). At the surface, mass concentrations of $\mathrm{WSOM}_{\mathrm{g}}$ in $\mathrm{MGLY}_{\text {equiv }}$ are high throughout the US, typically $>20 \mu \mathrm{g} \mathrm{m}^{-3}$ (Fig. 2). MGLY equiv $_{\text {concen- }}$ trations suggest organic gas-phase inventories are soluble throughout the US (Fig. 2a). When the entire model column is considered (up to $100 \mathrm{mb}$ ), mass concentrations of WSOM 

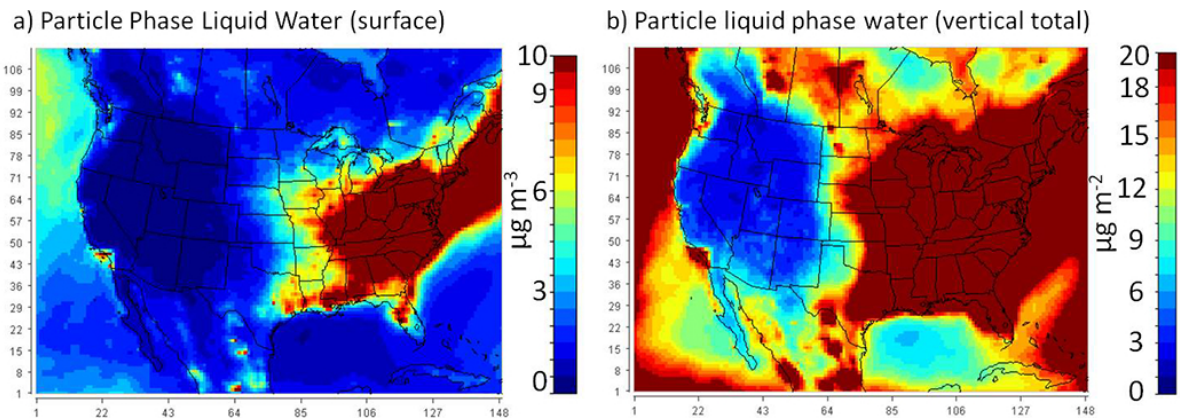

Fig. 4. (a)Particle-phase liquid water concentrations at the surface (0-34 m) and (b) for the model column (surface up to $100 \mathrm{mb})$. Values are July 2003 averages.

a) water vapor mixing ratio

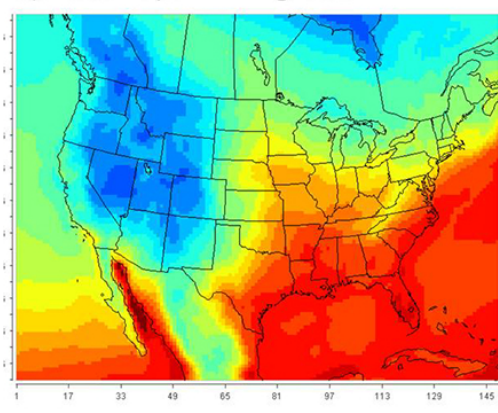

b) Aiken and accumulation mode $\mathrm{H}+$
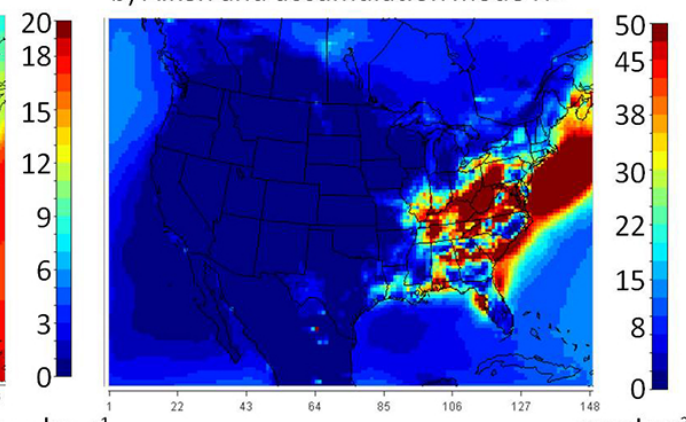

Fig. 5. Water vapor mixing ratio (a) and aerosol-free acidity (b) at the surface averaged for July 2003.

in MGLY $_{\text {equiv }}$ are ubiquitously large (typically $>500 \mu \mathrm{g} \mathrm{m}^{-2}$ ) and greatest in the western US $\left(>1 \mathrm{mg} \mathrm{m}^{-2}\right.$ ) (Fig. 2b). Tropospheric gas-phase organic inventories over the continental US are highly water-soluble, whether evaluated in mixing ratios, mass concentrations or MGLY equiv.

\subsection{WSOM aqueous partitioning potential is high in the Eastern US}

The instantaneous potential for gas-phase water-soluble organic matter to partition to particle-phase liquid water is large in surface air in the Eastern US and small elsewhere, with the exception of an area near Los Angeles, CA (Fig. 3 and Supplement) and "hot spots" in Mexico. A similar trend is observed when the entire column is considered. Unlike watersoluble gas concentrations (WSOMg, MGLY $_{\text {equiv }}$ ), this "liquid water partitioning potential" is not spatially ubiquitous. This phenomenon is explained by spatial patterns in $\mathrm{H}_{2} \mathrm{O}_{\text {ptcl }}$ mass concentrations (Fig. 4). The abundance of $\mathrm{H}_{2} \mathrm{O}_{\text {ptcl }}$ is a function of the mixing ratio of water vapor in the atmosphere and the concentration and hygroscopicity of the aerosol. Water vapor mixing ratios are highest in the Eastern US, as are aerosol-free acidity concentrations (Fig. 5). The abundance of aerosol-free acidity in the Eastern US is influenced to a large degree by anthropogenic $\mathrm{SO}_{2}$ emissions and the subsequent sulfate aerosol mass concentrations. Other contributors to aerosol acidity $\left(\mathrm{NO}_{3}, \mathrm{Cl}\right)$ do not contribute substantially to un-neutralized $\mathrm{H}+$ and are not visible when plotted at the same scale in Fig. 6 for this simulation. The total aerosolfree acidity $\left(\sim 50 \mathrm{nmol} \mathrm{m}^{-3}\right)$ is less than the sulfate acidity $\left(\sim 200 \mathrm{nmol} \mathrm{m}^{-3}\right)$ due to the neutralization of ammonium. In these simulations, particle-phase acidity and the resulting $\mathrm{H}_{2} \mathrm{O}$ uptake are anthropogenic in surface air over the continental US.

The simulated increase in partitioning potential when liquid water is available is consistent with ambient observations. Hennigan et al. (2008, 2009), and Sorooshian et al. (2010), find that when liquid water is available, the fraction of WSOM found in the particle-phase increases with increasing sub-saturated relative humidity (Hennigan et al., 2008, 2009; Sorooshian et al., 2010). Particle-phase WSOM also increases with increasing aerosol hygroscopicity (Sorooshian et al., 2010). This work suggests that because gas-phase WSOM is ubiquitous and $\mathrm{H}_{2} \mathrm{O}_{\text {ptcl }}$ is not, the availability of particle-phase liquid water caused by anthropogenic influences is the limiting factor in $\mathrm{SOA}_{\mathrm{AQ}}$ formation over the continental US.

CMAQ-estimated polar, water-soluble gases are more abundant than semi-volatile organic gases and particle-phase liquid water is more abundant than dry organic aerosol mass in the summertime over the US. In many locations, in 
a) Particle $\left[\mathrm{H}^{+}\right]$due to $\mathrm{SO}_{4}^{2-}$

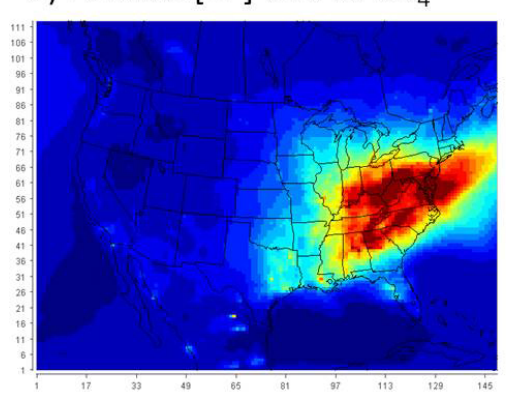

b) Particle $\left[\mathrm{H}^{+}\right]$due to $\mathrm{NH}_{4}^{+}$

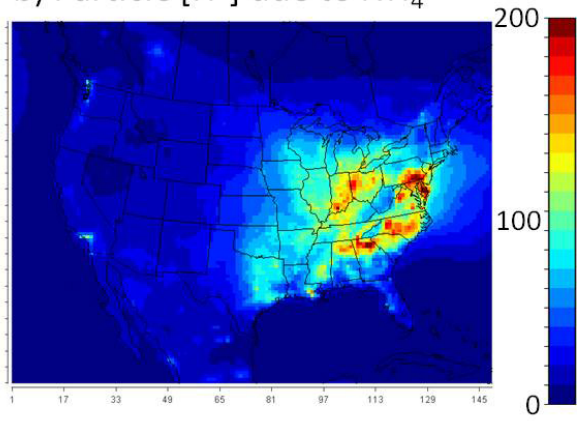

$\mathrm{nmol} \mathrm{m} \mathrm{m}^{-3}$

Fig. 6. Particle-phase $\mathrm{H}^{+}$concentration due to sulfate (a) and the neutralizing concentration of ammonium (b). Values are averaged for July 2003.

a) Gas Phase Water Soluble OC

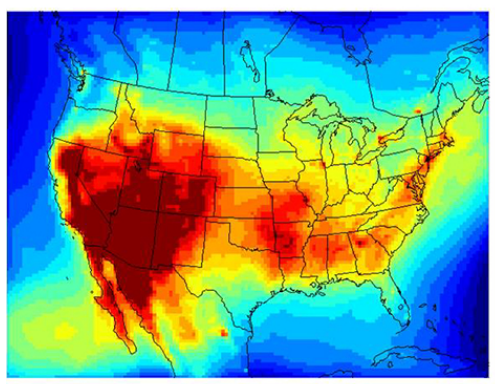

c) Particle Phase Liquid Water

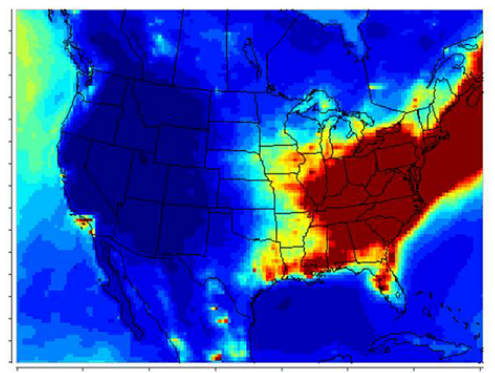

b) Gas Phase Semi-volatile OC

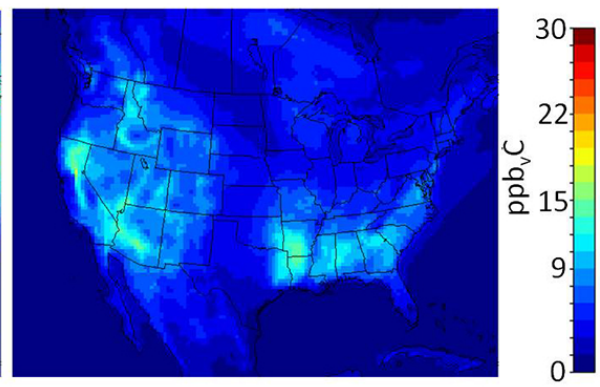

d) Particle Phase Organic Mass

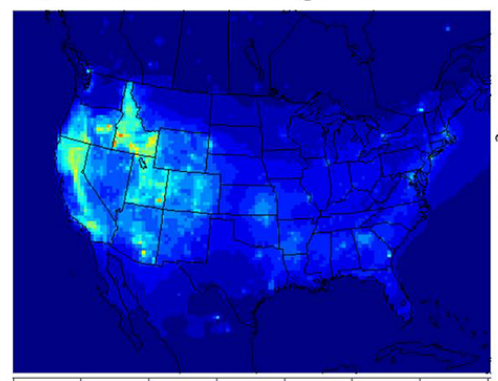

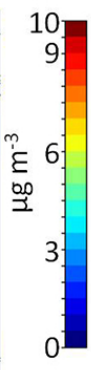

Fig. 7. Qualitative comparison of the potential of water-soluble gases to partition to aerosol water (left) versus the potential of semi-volatile gases to partition particle-phase organic matter (right). All values are averaged for July 2003. Included are species for which laboratory experiments have been conducted, as in Fig. 1.

particular the eastern US, the chemical potential for aqueous partitioning (water-soluble gases to particle liquid water) appears to be greater than the potential for semi-volatile gases to partition to dry OM (Fig. 7). Thus, unless condensed phase yields of low-volatility products are substantially different (order of magnitude), we expect that $\mathrm{SOA}_{\mathrm{AQ}}$ will be more important than $\mathrm{SOA}_{\text {gas }}$ in the Eastern US. It also seems that the overall geographic distribution of $\mathrm{SOA}_{\text {gas }}$ and $\mathrm{SOA}_{\mathrm{AQ}}$ are driven predominantly by the geographic distribution of $\mathrm{OM}$ and $\mathrm{H}_{2} \mathrm{O}_{\text {ptcl }}$, which are spatially limited compared to the organic precursor gases.

\subsection{Biogenic SOA is controllable}

Insights gained from this work lead us to hypothesize that biogenic SOA is abundant in the Southeastern US (Kleindienst et al., 2007; Lewandowski et al., 2007; Hennigan et al., 2008, 2009; Kleindienst et al., 2010) but lower in the Amazon (Pöschl et al., 2010; Martin et al., 2010) because $\mathrm{H}_{2} \mathrm{O}_{\text {ptcl }}$ concentrations are high (and anthropogenic) in the SE US but low in the Amazon. Global predictions of $\mathrm{H}_{2} \mathrm{O}_{\text {ptcl }}$ by Liao and Seinfeld (2005) support this idea. This work suggests $\mathrm{SO}_{2}$ pollution contributes to biogenic SOA mass concentrations in the eastern US through mechanisms not currently 
accounted for in atmospheric models. Carlton et al. (2010b) previously estimated that anthropogenic pollution accounts for approximately half of biogenic SOA (SOA formed from biogenic hydrocarbons) in the eastern US. The framework herein identifies another mechanism by which anthropogenic pollution can facilitate "biogenic" SOA production, and suggests that previous estimates of the controllable fraction of biogenic SOA are too low.

\section{Conclusions}

Over the continental US water-soluble organic gases demonstrated to form SOA through aqueous-phase chemistry are ubiquitous in the troposphere during the summertime. In the Eastern US, the potential for organic gases to partition to liquid water is greater than the potential to partition to particlephase organic matter. Partitioning of organic material to the condensed phase is limited by controllable mass concentrations of $\mathrm{H}_{2} \mathrm{O}_{\mathrm{ptcl}}$. Future investigations regarding the controllable fraction of organic aerosol should include simultaneous explicit phase partitioning of water-soluble and semi-volatile gases to condensed organic matter and liquid water.

\section{Supplementary material related to this article is available online at http://www.atmos-chem-phys.net/13/ 10203/2013/acp-13-10203-2013-supplement.pdf.}

Acknowledgements. This publication was made possible, in part, by USEPA (grant 83504101) and the US NSF (grant AGS1052611). Its contents are solely the responsibility of the grantee and do not necessarily represent the official views of the US EPA. Further, US EPA does not endorse the purchase of any commercial products or services mentioned in the publication.

Edited by: M. C. Facchini

\section{References}

Altieri, K. E., Carlton, A. G., Turpin, B. J., and Seitzinger, S.: Formation of Oligomers in Cloud-Processing: Reactions of Isoprene Oxidation Products, Environ. Sci. Technol., 40, 49564960, 2006.

Altieri, K. E., Seitzinger, S. P., Carlton, A. G., Turpin, B. J., Klein, G. C., and Marshall, A. G.: Oligomers formed through in-cloud methylglyoxal reactions: chemical composition, properties, and mechanisms investigated by ultra-high resolution FT-ICR mass spectrometry, Atmos. Environ., 42, 1476-1490, 2008.

Atkinson, R. and Arey, J.: Atmospheric degradation of volatile organic compounds, Chem. Rev., 103, 4605-4638, 2003.

Blando, J. D. and Turpin, B. J.: Secondary organic aerosol formation in cloud and fog droplets: A literature evaluation of plausibility, Atmos. Environ., 34, 1623-1632, 2000.
Budisulistiorini, S. H., Canagaratna, M. R., Croteau, P. L., Marth, W. J., Baumann, K., Edgerton, E. S., Shaw, S. L., Knipping, E. M., Worsnop, D. R., Jayne, J. T., Gold, A., and Surratt, J. D.: Real-time continuous characterization of secondary organic aerosol derived from isoprene epoxydiols in downtown Atlanta, Georgia, using the Aerodyne Aerosol Chemical Speciation Monitor, Environ. Sci. Technol., 47, 5686-5694, 2013.

Canepari, S., Farao, C., Marconi, E., Giovannelli, C., and Perrino, C.: Qualitative and quantitative determination of water in airborne particulate matter, Atmos. Chem. Phys., 13, 1193-1202, doi:10.5194/acp-13-1193-2013, 2013.

Carlton, A. G. and Baker, K.: Photochemical modeling of the Ozark isoprene volcano: MEGAN, BEIS and their impacts on air quality predictions, Environ. Sci. Technol., 45, 4438-4445, 2011.

Carlton, A. G., Lim, H.-J., Altieri, K., Seitinger, S., and Turpin, B. J.: Link Between Isoprene and SOA: fate of pyruvic acid in dilute aqueous solution, Geophys. Res. Letts., 33, L06822, doi:10.1029/2005g1025374, 2006.

Carlton, A. G., Turpin, B. J., Altieri, K. E., Reff, A., Seitzinger, S., Lim, H. J., and Ervens, B.: Atmospheric Oxalic Acid and SOA Production from Glyoxal: Results of Aqueous Photooxidation Experiments, Atmos. Environ., 41, 7588-7602, 2007.

Carlton, A. G., Turpin, B. J., Altieri, K. E., Seitzinger, S. P., Mathur, R., Roselle, S. J., and Weber, R. J.: CMAQ model performance enhanced when in-cloud SOA is included: comparisons of OC predictions with measurements, Environ. Sci. Technol., 42, 8798-8802, 2008.

Carlton, A. G., Bhave, P. V., Napelenok, S. L., Edney, E. O., Sarwar, G., Pinder, R. W., Pouliot, G. A., and Houyoux, M.: Treatment of secondary organic aerosol in CMAQv4.7, Environ. Sci. Technol., 44, 8553-8560, 2010a.

Carlton, A. G., Pinder, R. W., Bhave, P. V., and Pouliot, G. A.: To What Extent Can Biogenic SOA be Controlled?, Environ. Sci. Technol., 44, 3376-3380, 2010b.

Chameides, W. L., Fehsenfeld, F., Rodgers, M. O., Cardelino, C., Martinez, J., Parrish, D., Lonneman, W., Lawson, D. R., Rasmussen, R. A., Zimmerman, P., Greenberg, J., Middleton, P., and Wang, T.: Ozone precursor relationships in the ambient atmosphere, J. Geophys. Res.-Atmos., 97, 6037-6055, 1992.

Chan, M. N., Surratt, J. D., Claeys, M., Edgerton, E. S., Tanner, R. L., Shaw, S. L., Zheng, M., Knipping, E. M., Eddingsaas, N. C., Wennberg, P. O., and Seinfeld, J. H.: Characterization and Quantification of Isoprene-Derived Epoxydiols in Ambient Aerosol in the Southeastern United States, Environ. Sci. Technol., 44, 45904596, 2010.

Chang, W. L., Griffin, R. J., and Dabdub, D.: Partitioning phase preference for secondary organic aerosol in an urban atmosphere, P. Natl. Acad. Sci. USA, 107, 6705-6710, 2010.

Chebbi, A. and Carlier, P.: Carboxylic Acids in the Troposphere, Occurrence, Sources, and Sinks: a Review, Atmos. Environ., 30, 4233-4249, 1996.

De Gouw, J. and Jimenez, J. L.: Organic Aerosols in the Earth's Atmosphere, Environ. Sci. Technol., 43, 7614-7618, 2009.

De Haan, D. O., Corrigan, A. L., Smith, K. W., Stroik, D. R., Turley, J. J., Lee, F. E., Tolbert, M. A., Jimenez, J. L., Cordova, K. E., and Ferrell, G. R.: Secondary Organic Aerosol-Forming Reactions of Glyoxal with Amino Acids, Environ. Sci. Technol., 43, 28182824, 2009a. 
De Haan, D. O., Tolbert, M. A., and Jimenez, J. L.: Atmospheric condensed-phase reactions of glyoxal with methylamine, Geophys. Res. Lett., 36, L11819, doi:10.1029/2009g1037441, 2009 b.

Dick, W. D., Saxena, P., and McMurry, P. H.: Estimation of water uptake by organic compounds in submicron aerosols measured during the Southeastern Aerosol and Visibility Study, J. Geophys. Res.-Atmos., 105, 1471-1479, 2000.

Ding, X., Zheng, M., Yu, L. P., Zhang, X. L., Weber, R. J., Yan, B., Russell, A. G., Edgerton, E. S., and Wang, X. M.: Spatial and seasonal trends in biogenic secondary organic aerosol tracers and water-soluble organic carbon in the southeastern United States, Environ. Sci. Technol., 42, 5171-5176, 2008.

El Haddad, I., Yao Liu, Nieto-Gligorovski, L., Michaud, V., Temime-Roussel, B., Quivet, E., Marchand, N., Sellegri, K., and Monod, A.: In-cloud processes of methacrolein under simulated conditions - Part 2: Formation of secondary organic aerosol, Atmos. Chem. Phys., 9, 5107-5117, doi:10.5194/acp-9-5107-2009, 2009

Ervens, B., Turpin, B. J., and Weber, R. J.: Secondary organic aerosol formation in cloud droplets and aqueous particles (aqSOA): a review of laboratory, field and model studies, Atmos. Chem. Phys., 11, 11069-11102, doi:10.5194/acp-1111069-2011, 2011

Galloway, M. M., Chhabra, P. S., Chan, A. W. H., Surratt, J. D., Flagan, R. C., Seinfeld, J. H., and Keutsch, F. N.: Glyoxal uptake on ammonium sulphate seed aerosol: reaction products and reversibility of uptake under dark and irradiated conditions, Atmos. Chem. Phys., 9, 3331-3345, doi:10.5194/acp-9-3331-2009, 2009.

Grgic, I., Nieto-Gligorovski, L. I., Net, S., Temime-Roussel, B., Gligorovski, S., and Wortham, H.: Light induced multiphase chemistry of gas-phase ozone on aqueous pyruvic and oxalic acids, Phys. Chem. Chem. Phys., 12, 698-707, 2010.

Griffin, R. J., Cocker, D. R., Flagan, R. C., and Seinfeld, J. H.: Organic aerosol formation from the oxidation of biogenic hydrocarbons, J. Geophys. Res.-Atmos., 104, 3555-3567, 1999.

Guzman, M. I., Colussi, A. I., and Hoffmann, M. R.: Photoinduced oligomerization of aqueous pyruvic acid, J. Phys. Chem. A, 110, 3619-3626, 2006.

Ham, J. E., Proper, S. P., and Wells, J. R.: Gas-phase chemistry of citronellol with ozone and $\mathrm{OH}$ radical: Rate constants and products, Atmos. Environ., 40, 726-735, 2006.

Hatch, L. E., Creamean, J. M., Ault, A. P., Surratt, J. D., Chan, M. N., Seinfeld, J. H., Edgerton, E. S., Su, Y., and Prather, K. A.: Measurements of Isoprene-Derived Organosulfates in Ambient Aerosols by Aerosol Time-of-Flight Mass Spectrometry - Part 2: Temporal Variability and Formation Mechanisms, Environ. Sci. Technol., 45, 8648-8655, 2011.

Hennigan, C. J., Bergin, M. H., Dibb, J. E., and Weber, R. J.: Enhanced secondary organic aerosol formation due to water uptake by fine particles, Geophys. Res. Letts., 35, L18801, doi:10.1029/2008g1035046, 2008.

Hennigan, C. J., Bergin, M. H., Russell, A. G., Nenes, A., and Weber, R. J.: Gas/particle partitioning of water-soluble organic aerosol in Atlanta, Atmos. Chem. Phys., 9, 3613-3628, doi:10.5194/acp-9-3613-2009, 2009.

Ho, K. F., Lee, S. C., Cao, J. J., Kawamura, K., Watanabe, T., Cheng, Y., and Chow, J. C.: Dicarboxylic acids, ketocarboxylic acids and dicarbonyls in the urban roadside area of Hong Kong, Atmos. Environ., 40, 3030-3040, 2006.

Houyoux, M. R., Vukovich, J. M., Coats, C. J., Wheeler, N. J. M., and Kasibhatla, P. S.: Emission inventory development and processing for the Seasonal Model for Regional Air Quality (SMRAQ) project, J. Geophys. Res.-Atmos., 105, 9079-9090, 2000.

Huang, D., Zhang, X., Chen, Z. M., Zhao, Y., and Shen, X. L.: The kinetics and mechanism of an aqueous phase isoprene reaction with hydroxyl radical, Atmos. Chem. Phys., 11, 7399-7415, doi:10.5194/acp-11-7399-2011, 2011.

Kleindienst, T. E., Jaoui, M., Lewandowski, M., Offenberg, J. H., Lewis, C. W., Bhave, P. V., and Edney, E. O.: Estimates of the contributions of biogenic and anthropogenic hydrocarbons to secondary organic aerosol at a southeastern US location, Atmos. Environ., 41, 8288-8300, 2007.

Kleindienst, T. E., Lewandowski, M., Offenberg, J. H., Edney, E. O., Jaoui, M., Zheng, M., Ding, X. A., and Edgerton, E. S.: Contribution of Primary and Secondary Sources to Organic Aerosol and PM2.5 at SEARCH Network Sites, J. Air Waste Manage., 60, 1388-1399, 2010

Kroll, J. H., Ng, N. L., Murphy, S. M., Varutbangkul, V., Flagan, R. C., and Seinfeld, J. H.: Chamber studies of secondary organic aerosol growth by reactive uptake of simple carbonyl compounds, J. Geophys. Res., 110, D23207, doi:10.1029/2005jd006004, 2005.

Lane, T. E., Donahue, N. M., and Pandis, S. N.: Effect of $\mathrm{NO}_{\mathrm{x}}$ on secondary organic aerosol concentrations, Environ. Sci. Technol., 42, 6022-6027, 2008.

Lee, A. K. Y., Herckes, P., Leaitch, W. R., Macdonald, A M., and Abbatt, J. P. D.: Aqueous $\mathrm{OH}$ oxidation of ambient organic aerosol and cloud water organics: Formation of highly oxidized products, Geophys. Res. Lett., 38, L11805, doi:10.1029/2011gl047439, 2011.

Lewandowski, M., Jaoui, M., Kleindienst, T. E., Offenberg, J. H., and Edney, E. O.: Composition of $\mathrm{PM}_{2.5}$ during the summer of 2003 in Research Triangle Park, North Carolina, Atmos. Environ., 41, 4073-4083, 2007.

Lewis, C. W., Klouda, G. A., and Ellenson, W. D.: Radiocarbon measurement of the biogenic contribution to summertime PM-2.5 ambient aerosol in Nashville, TN, Atmos. Environ., 38 , 6053-6061, 2004

Li, Y. C. and Yu, J. Z.: Simultaneous determination of mono- and dicarboxylic acids, omega-oxo-carboxylic acids, midchain ketocarboxylic acids, and aldehydes in atmospheric aerosol samples, Environ. Sci. Technol., 39, 7616-7624, 2005.

Li, Z., Schwier, A. N., Sareen, N., and McNeill, V. F.: Reactive processing of formaldehyde and acetaldehyde in aqueous aerosol mimics: surface tension depression and secondary organic products, Atmos. Chem. Phys., 11, 11617-11629, doi:10.5194/acp11-11617-2011, 2011.

Liao, H. and Seinfeld, J. H.: Global impacts of gas-phase chemistryaerosol interactions on direct radiative forcing by anthropogenic aerosols and ozone, J. Geophys. Res., 110, D18208, doi:10.1029/2005jd005907, 2005.

Liu, J., Horowitz, L. W., Fan, S., Levy, H., and Carlton, A. G.: Global in-cloud production of secondary organic aerosols: implementation of a detailed chemical mechanism in the GFDL atmospheric model AM3, J. Geophys. Res., 117, D15303, doi:10.1029/2012jd017838, 2012a. 
Liu, Y., Monod, A., Tritscher, T., Praplan, A. P., DeCarlo, P. F., Temime-Roussel, B., Quivet, E., Marchand, N., Dommen, J., and Baltensperger, U.: Aqueous phase processing of secondary organic aerosol from isoprene photooxidation, Atmos. Chem. Phys., 12, 5879-5895, doi:10.5194/acp-12-5879-2012, 2012 b.

Liu, Y., Siekmann, F., Renard, P., El Zein, A., Salque, G., El Haddad, I., Temime-Roussel, B., Voisin, D., Thissen, R., and Monod, A.: Oligomer and SOA formation through aqueous phase photooxidation of methacrolein and methyl vinyl ketone, Atmos. Environ., 49, 123-129, 2012c.

Malm, W. C., Sisler, J. F., Huffman, D., Eldred, R. A., and Cahill, T. A.: Spatial and seasonal trends in particle concentration and optical extinction in the United States, J. Geophys. Res., 99, 13471370, 1994.

Martin, S. T., Andreae, M. O., Althausen, D., Artaxo, P., Baars, H., Borrmann, S., Chen, Q., Farmer, D. K., Guenther, A., Gunthe, S. S., Jimenez, J. L., Karl, T., Longo, K., Manzi, A., Müller, T., Pauliquevis, T., Petters, M. D., Prenni, A. J., Pöschl, U., Rizzo, L. V., Schneider, J., Smith, J. N., Swietlicki, E., Tota, J., Wang, J., Wiedensohler, A., and Zorn, S. R.: An overview of the Amazonian Aerosol Characterization Experiment 2008 (AMAZE08), Atmos. Chem. Phys., 10, 11415-11438, doi:10.5194/acp10-11415-2010, 2010.

Moortgat, G. K., Grossmann, D., Boddenberg, A., Dallmann, G., Ligon, A. P., Turner, W. V., Gab, S., Slemr, F., Wieprecht, W., Acker, K., Kibler, M., Schlomski, S., and Bachmann, K.: Hydrogen peroxide, organic peroxides and higher carbonyl compounds determined during the BERLIOZ campaign, J. Atmos. Chem., 42, 443-463, 2002.

Munger, J. W., Jacob, D. J., and Hoffmann, M. R.: The occurrence of bisulfite-aldehyde addition products in fog- and cloud-water, J. Atmos. Chem., 1, 335-350, 1984.

Nenes, A., Pandis, S. N., and Pilinis, C.: Continued development and testing of a new thermodynamic aerosol module for urban and regional air quality models, Atmos. Environ., 33, 15531560, 1999.

Ng, N. L., Kroll, J. H., Chan, A. W. H., Chhabra, P. S., Flagan, R. C., and Seinfeld, J. H.: Secondary organic aerosol formation from $m$-xylene, toluene, and benzene, Atmos. Chem. Phys., 7, 3909-3922, doi:10.5194/acp-7-3909-2007, 2007.

Nguyen, T. B., Lee, P. B., Updyke, K. M., Bones, D. L., Laskin, J., Laskin, A., and Nizkorodov, S. A.: Formation of nitrogenand sulfur-containing light-absorbing compounds accelerated by evaporation of water from secondary organic aerosols, J. Geophys. Res., 117, D01207, doi:10.1029/2011jd016944, 2012.

Nolte, C. G., Fraser, M. P., and Cass, G. R.: Gas phase C-2-C-10 organic acids concentrations in the Los Angeles atmosphere, Environ. Sci. Technol., 33, 540-545, 1999.

Noziere, B. and Cordova, A.: A kinetic and mechanistic study of the amino acid catalyzed aldol condensation of acetaldehyde in aqueous and salt solutions, J. Phys. Chem. A, 112, 2827-2837, 2008.

Noziere, B., Dziedzic, P., and Cordova, A.: Products and Kinetics of the Liquid-Phase Reaction of Glyoxal Catalyzed by Ammonium Ions (NH4+), J. Phys. Chem. A, 113, 231-237, 2009.

Noziere, B., Ekstrom, S., Alsberg, T., and Holmstrom, S.: Radical-initiated formation of organosulfates and surfactants in atmospheric aerosols, Geophys. Res. Lett., 37, L05806, doi:10.1029/2009g1041683, 2010.
Odum, J. R., Hoffmann, T., Bowman, F., Collins, D., Flagan, R. C., and Seinfeld, J. H.: Gas/particle partitioning and secondary organic aerosol yields, Environ. Sci. Technol., 30, 2580-2585, 1996.

Ortiz-Montalvo, D. L., Lim, Y. B., Perri, M. J., Seitzinger, S. P., and Turpin, B. J.: Volatility and Yield of Glycolaldehyde SOA Formed through Aqueous Photochemistry and Droplet Evaporation, Aerosol Sci. Technol., 46, 1002-1014, 2012.

Pankow, J. F.: An absorption model of the gas/aerosol partitioning involved in the formation of secondary organic aerosol, Atmos. Environ., 28, 189-193, 1994.

Parikh, H. M., Carlton, A. G., Vizuete, W., and Kamens, R. M.: Modeling secondary organic aerosol using a dynamic partitioning approach incorporating particle aqueous-phase chemistry, Atmos. Environ., 45, 1126-1137, 2011.

Parikh, H. M., Carlton, A. G., Zhou, Y., Zhang, H., Kamens, R. M., and Vizueter, W.: Modeling secondary organic aerosol formation from xylene and aromatic mixtures using a dynamic partitioning approach incorporating particle aqueous-phase chemistry (II), Atmos. Environ., 56, 250-260, 2012.

Paulot, F., Crounse, J. D., Kjaergaard, H. G., Kurten, A., St Clair, J. M., Seinfeld, J. H., and Wennberg, P. O.: Unexpected epoxide formation in the gas-phase photooxidation of isoprene, Science, 325, 730-733, 2009.

Paulson, S. E. and Seinfeld, J. H.: Development and evaluation of a photooxidation mechanism for isoprene, J. Geophys. Res., 97, 20703-720715, 1992.

Perri, M. J., Seitzinger, S., and Turpin, B. J.: Secondary organic aerosol production from aqueous photooxidation of glycolaldehyde: Laboratory experiments, Atmos. Environ., 43, 1487-1497, 2009.

Perri, M. J., Lim, Y. B., Seitzinger, S. P., and Turpin, B. J.: Organosulfates from glycolaldehyde in aqueous aerosols and clouds: Laboratory studies, Atmos. Environ., 44, 2658-2664, 2010.

Pierce, T., Geron, C., Bender, L., Dennis, R., Tonnesen, G., and Guenther, A.: Influence of increased isoprene emissions on regional ozone modeling, J. Geophys. Res.-Atmos., 103, 2561125629, 1998.

Pöschl, U., Martin, S. T., Sinha, B., Chen, Q., Gunthe, S. S., Huffman, J. A., Borrmann, S., Farmer, D. K., Garland, R. M., Helas, G., Jimenez, J. L., King, S. M., Manzi, A., Mikhailov, E., Pauliquevis, T., Petters, M. D., Prenni, A. J., Roldin, P., Rose, D., Schneider, J., Su, H., Zorn, S. R., Artaxo, P., and Andreae, M. O.: Rainforest Aerosols as Biogenic Nuclei of Clouds and Precipitation in the Amazon, Science, 329, 15131516, doi:10.1126/science.1191056, 2010.

Poulain, L., Katrib, Y., Isikli, E., Liu, Y., Wortham, H., Mirabel, P., Le Calve, S., and Monod, A.: In-cloud multiphase behaviour of acetone in the troposphere: Gas uptake, Henry's law equilibrium and aqueous phase photooxidation, Chemosphere, 81, 312-320, 2010.

Pun, B. K., Griffin, R. J., Seigneur, C., and Seinfeld, J. H.: Secondary organic aerosol -2 . Thermodynamic model for gas/particle partitioning of molecular constituents, J. Geophys. Res., 107, 4333, doi:10.1029/2001JD000542, 2002.

Sareen, N., Schwier, A. N., Shapiro, E. L., Mitroo, D., and McNeill, V. F.: Secondary organic material formed by methylglyoxal 
in aqueous aerosol mimics, Atmos. Chem. Phys., 10, 997-1016, doi:10.5194/acp-10-997-2010, 2010.

Sareen, N., Schwier, A. N., Lathem, T. L., Nenes, A., and McNeill, V. F.: Surfactants from the gas phase may promote cloud droplet formation, P. Natl. Acad. Sci. USA, 110, 2723-2728, 2013.

Seinfeld, J. H. and Pankow, J. F.: Organic Atmospheric Particulate Material, Ann. Rev. Phys. Chem., 54, 121-140, 2003.

Shapiro, E. L., Szprengiel, J., Sareen, N., Jen, C. N., Giordano, M. R., and McNeill, V. F.: Light-absorbing secondary organic material formed by glyoxal in aqueous aerosol mimics, Atmos. Chem. Phys., 9, 2289-2300, doi:10.5194/acp-9-2289-2009, 2009.

Smith, D. F., Kleindienst, T. E., and McIver, C. D.: Primary product distributions from the reaction of $\mathrm{OH}$ with $\mathrm{m}-$, $\mathrm{p}$-xylene, 1,2,4- and 1,3,5-trimethylbenzene, J. Atmos. Chem., 34, 339364, 1999.

Sorooshian, A., Murphy, S. M., Hersey, S., Bahreini, R., Jonsson, H., Flagan, R. C., and Seinfeld, J. H.: Constraining the contribution of organic acids and AMS m/z 44 to the organic aerosol budget: On the importance of meteorology, aerosol hygroscopicity, and region, Geophys. Res. Lett., 37, L21807, doi:10.1029/2010g1044951, 2010.

Spaulding, R. S., Frazey, P., Rao, X., and Charles, M. J.: Measurement of hydroxy carbonyls and other carbonyls in ambient air using pentafluorobenzyl alcohol as a chemical ionization reagent, Anal. Chem., 71, 3420-3427, 1999.

Spaulding, R. S., Schade, G. W., Goldstein, A. H., and Charles, M. J.: Characterization of secondary atmospheric photooxidation products: Evidence for biogenic and anthropogenic sources, J. Geophy. Res., 108, 4247, doi:10.1029/2002JD002478, 2003.

Sun, Y. L., Zhang, Q., Anastasio, C., and Sun, J.: Insights into secondary organic aerosol formed via aqueous-phase reactions of phenolic compounds based on high resolution mass spectrometry, Atmos. Chem. Phys., 10, 4809-4822, doi:10.5194/acp-104809-2010, 2010.

Tan, Y., Carlton, A. G., Seitzinger, S. P., and Turpin, B. J.: SOA from methylglyoxal in clouds and wet aerosols: measurement and prediction of key products, Atmos. Environ., 44, 5218-5226, 2010.

Tan, Y., Lim, Y. B., Altieri, K. E., Seitzinger, S. P., and Turpin, B. J.: Mechanisms leading to oligomers and SOA through aqueous photooxidation: insights from $\mathrm{OH}$ radical oxidation of acetic acid and methylglyoxal, Atmos. Chem. Phys., 12, 801-813, doi:10.5194/acp-12-801-2012, 2012.
Volkamer, R., Ziemann, P. J., and Molina, M. J.: Secondary Organic Aerosol Formation from Acetylene $\left(\mathrm{C}_{2} \mathrm{H}_{2}\right)$ : seed effect on SOA yields due to organic photochemistry in the aerosol aqueous phase, Atmos. Chem. Phys., 9, 1907-1928, doi:10.5194/acp9-1907-2009, 2009

Wang, G. H., Niu, S. L., Liu, C., and Wang, L. S.: Identification of dicarboxylic acids and aldehyde of $\mathrm{PM}_{10}$ and $\mathrm{PM}_{2.5}$ aerosols in Nanjing, China, Atmos. Environ., 36, 1941-1950, 2002.

Yao Liu, El Haddad, I., Scarfogliero, M., Nieto-Gligorovski, L., Temime-Roussel, B., Quivet, E., Marchand, N., Picquet-Varrault, B., and Monod, A.: In-cloud processes of methacrolein under simulated conditions - Part 1: Aqueous phase photooxidation, Atmos. Chem. Phys., 9, 5093-5105, doi:10.5194/acp-9-50932009, 2009.

Yasmeen, F., Sauret, N., Gal, J.-F., Maria, P.-C., Massi, L., Maenhaut, W., and Claeys, M.: Characterization of oligomers from methylglyoxal under dark conditions: a pathway to produce secondary organic aerosol through cloud processing during nighttime, Atmos. Chem. Phys., 10, 3803-3812, doi:10.5194/acp-103803-2010, 2010.

Zarzana, K. J., De Haan, D. O., Freedman, M. A., Hasenkopf, C. A., and Tolbert, M. A.: Optical Properties of the Products of alphaDicarbonyl and Amine Reactions in Simulated Cloud Droplets, Environ. Sci. Technol., 46, 4845-4851, 2012.

Zhang, X., Chen, Z. M., and Zhao, Y.: Laboratory simulation for the aqueous $\mathrm{OH}$-oxidation of methyl vinyl ketone and methacrolein: significance to the in-cloud SOA production, Atmos. Chem. Phys., 10, 9551-9561, doi:10.5194/acp-10-9551-2010, 2010.

Zhou, Y., Zhang, H. F., Parikh, H. M., Chen, E. H., Rattanavaraha, W., Rosen, E. P., Wang, W. X., and Kamens, R. M.: Secondary organic aerosol formation from xylenes and mixtures of toluene and xylenes in an atmospheric urban hydrocarbon mixture: Water and particle seed effects (II), Atmos. Environ., 45, 3882-3890, 2011.

Zuend, A. and Seinfeld, J. H.: Modeling the gas-particle partitioning of secondary organic aerosol: the importance of liquidliquid phase separation, Atmos. Chem. Phys., 12, 3857-3882, doi:10.5194/acp-12-3857-2012, 2012. 